Intersectionality

AYLWARD

\title{
Intersectionality: Crossing the Theoretical and Praxis Divide ${ }^{1}$
}

\author{
CCAROL A. AYLWARD ${ }^{2}$ \\ Dalhousie University
}

\begin{abstract}
The particular vulnerability to sexual assault that is experienced by women who are Aboriginal, disabled, or Black was discussed by the Coalition in its factum in O'Conner (paragraphs 17 to 24). Other cases will expose the particular operation and intersection of more inequalities that continue not to be acknowledged or challenged by a legal system that fails to invoke the guarantees of section 15. It is material to acknowledge that neither the O'Conner case nor the present appeal represent all the dynamics of power and institutionalized oppression to which women are subject. ${ }^{3}$
\end{abstract}

\section{Introduction}

In 1989, the Canadian Advisory Council on the Status of Women prepared an analysis of

1 This Article is a reproduction of a paper by the author distributed at the conference Transforming Women's Future: Equality Rights in the New Century: A National Forum on Equality Rights, presented by West Coast Leaf, 4 November, (1999) [previously unpublished].

${ }^{2}$ Carol Aylward is an Associate Professor at Dalhousie Law School, and the former Director of the Indigenous Blacks and Mi'kmaq Programme at Dalhousie Law School. Portions of this Article discussing Black Feminist theory have appeared in a previous book by the author entitled Canadian Critical Race Theory: Racism and the Law, 1999. Halifax: Fernwood Publishing.

${ }^{3}$ A.(L.L.) v. Beharrll, Factum of the Aboriginal Women's Council et al., in Equality and the Charter: Ten Years of Feminist Advocacy Before the Supreme Court of Canada, Women's Legal Education and Action Fund. 1996. Toronto: Edmond Montgomery Publications Limited at p. 454.

Volume 1, Number 1, 2010 
that:

We would have liked to explore more fully the application of the Charter's guarantees to the inequality of women who are discriminated against because of race, disability, or other grounds. Unfortunately, cases that challenge the particular complex of disadvantage experienced by women of colour or women with disabilities, for example, are virtually absent from the body of decisions. So far these cases are simply not reaching the courts. In the few cases that involve poor women and Lesbian women, sex equality arguments have not been advanced...[this] means that judges are not being presented with women's unique experience of discrimination based on race, social status, disability, age, sexual orientation, marital status, or religion. ${ }^{6}$

In the last twenty years ${ }^{7}$ racialized women, lesbian women, women with disabilities and women in poverty have criticized mainstream feminist theory and in particular the women's rights advocacy organization $\mathrm{LEAF}^{\mathbf{8}}$ for their non-responsiveness to the issues surrounding the

\footnotetext{
${ }^{4}$ Canadian Charter of Rights and Freedoms, Part I of the Constitution Act, 1982 [hereinafter the Charter].

${ }^{5}$ Gwen Brodsky and Shelia Day, "Canadian Charter Equality Rights for Women: One Step Forward or Two Steps Back?" (Ottawa: Canadian Advisory Council on the Status of Women, 1989).

${ }^{6}$ Canadian Advisory Council on the Status of Women, Supra, note 4, at pp.4-5.

7 Since the author's paper on Intersectionality was presented at the West Coast Leaf Conference in 1999 Critical Race scholars and other critical scholars (in Canada and elsewhere including the Ontario Human Rights Commission) have further developed Intersectional analysis and Critical Race Theory generally across varying disciplines. See for example: An Intersectional approach to discrimination: Addressing multiple grounds in Human Rights Claims, Discussion Paper, Ontario Human Rights Commission, Policy and Education Branch, 2001, Ontario Human Rights Commission http://www.ohrc.on.ca/en/resources/discussion; Emily Grabham, Davina Cooper, Jane Krishnadas, Didi Herman, eds., Intersectionality and Beyond: Law, Power and the Politics of Location, (Routledge-Cavendish, 2008); Margaret Denike, Sal Renshaw \& CJ Rowe, Transgender and Women's Substantive Equality, Discussion Paper, Consultation Paper, Bibliography, Case Law Summaries, National Association of Women and the Law (2003); Candice Metallic \& Patricia Monture-Angus, Domestic Laws versus Aboriginal Visions: An Analysis of the Delgamuukw Decision, Borderlands e-Journal, Volume 1 Number 2, (2002) http://www.borderlands.net.au/vol1no2 2002/metallic angus.html; Diana Majury, The Charter: Equality Rights, and Women: Equivocation and Celebration, 2002, Osgoode Hall Law Journal, Vol. 40, Nos. 3\&4; Patricia Monture-Angus, The Lived Experience of Discrimination: Aboriginal Women Who Are Federally Sentenced, (2002) http://www.elizabethfry.ca/caefs_e.htm; Elena Marchetti, Intersectional Race and Gender Analyses: Why Legal Processes Just Don't Get It, Social \& Legal Studies, Vol. 17, No. 2, 155-174 (2008); Morgan, Deborah A. , Not Gay Enough for the Government: Racial and Sexual Stereotypes in Sexual Orientation Asylum Cases, Law \& Sexuality 135-161 (2006).

${ }^{8}$ Legal Education and Action Fund: LEAF was founded to "contribute to the goal of advancing women's equality in Canada." See: Equality and the Charter: Ten Years of Feminist Advocacy before the Supreme Court of Canada", 1996. Ottawa: Women's Legal Education and Action Fund. LEAF was modelled after the American NAACP (National Association for the Advancement of Coloured People: Legal Defence and Education Fund).
} 
multiple oppressions experienced by women who were not White, middle class, heterosexual and able bodied. ${ }^{9}$ These criticisms have been levelled at mainstream feminism generally across North America. For example, Black feminists and other feminists of colour denounced mainstream feminism because it overlooked the fact that White supremacy and dominance impacted women of colour. ${ }^{\mathbf{1 0}}$ Critical Race Feminists argue that mainstream feminist theory has neglected Black women's and other women of colour's realities of racism, sexism and classism, and White women's role in this oppression. As a result of this neglect, Black feminists and other feminists of colour, reacted to this vacuum by pioneering a new genre known as "Critical Race Feminism", an off-shoot of Critical Race Theory which originated with Black and other scholars of colour who felt that existing legal discourse including the Critical Legal Studies discourse was alienating to all people of colour. ${ }^{11}$

Many Critical Race Feminists argue that Liberal feminist theory has been able to see the analogies between racism and sexism but, has been unable to develop a framework which encompasses both. ${ }^{\mathbf{1 2}}$ Socialist feminist theory, critics argue, focuses on the issue of class and gender without focusing on the 'racism of class'. Louis Kushnick argues, for example, that because institutional racism determines resource allocation such as access to goods and services

\footnotetext{
${ }^{9}$ Equality and the Charter: Ten Years of Feminist Advocacy Before the Supreme Court of Canada, Ibid., at p. xxi "LEAF has been criticized for failing to address women's inequality in all its complexity and diversity. This criticism is not without foundation. Because LEAF's founding board and staff were white, middle class professional women, there was legitimate scepticism of LEAF's ability to respond to and incorporate the interests and experiences of diverse women."

${ }^{10}$ See generally: Kathleen Cleaver, Racism, Civil Rights, and Feminism, in Adrien Katherine Wing (ed.), Critical Race Feminism: A Reader. New York: Ballantine Books. See also: Canadian Critical Race Theory: Racism and the Law, Supra, note 1, at p.35.

${ }^{11}$ See generally: Kathleen Cleaver, Racism, Civil Rights, and Feminism, in Adrien Katherine Wing (ed.), Critical Race Feminism: A Reader. New York: Ballantine Books. See also: Canadian Critical Race Theory: Racism and the Law, Supra, note 1, at p.35.

${ }^{12}$ Jacinth Herbert, "Otherness" and the Black Woman, 3 C.J.W.L. 269 at 271; In Canadian Critical Race Theory: Racism and the Law, Ibid.
} 
and opportunities including education, employment and the like, Whites get privileged access to scarce resources. This kind of inequality he argues maintains the class system by:

...inculcating and reinforcing a race consciousness rather than a class consciousness among the white working class...one has only to look at the history of 'race riots' -- pogroms -- against people of colour in times of economic and political crisis... and the current escalation of racial violence among unemployed and alienated whites. ${ }^{\mathbf{1 3}}$

Socialist feminist theory, while articulating the effects of 'class' on White women, fails to examine the intersection of 'race' and 'class' on women and men of colour. The ruling class, as Kushnick notes, expend a great deal of effort in separating race from class both intellectually and politically and he notes that the White working-class form of racism incorporates and maintains the racist ideology of the ruling class. ${ }^{14}$

On the other hand Radical feminism, which has as its primary focus the concept of patriarchy and emphasizes gender relations or sex oppression as the most crucial form of oppression, has denied the commonality of oppression that Black women have with Black men. For example, Angela Harris examines the issue of rape in order to demonstrate this commonality of oppression between Black women and Black men. She demonstrates that mainstream feminists like Katherine McKinnon have failed to explore in their analysis what rape means to Black women and Black men. Harris points out that for Black women, rape is a more complex phenomenon, and an "experience as deeply rooted in colour as in gender"

\footnotetext{
${ }^{13}$ Lois Kushnick, Race, Class \& Struggle: Essays on Racism and Inequality in Britain, the U.S. and Western Europe. 1998. London and New York: Rivers Oram Press, at 47. Reproduced in Canadian Critical Race Theory: Racism and the Law, Supra, note 1.

${ }^{14}$ Race, Class \& Struggle: Ibid. at 46.

${ }^{15}$ Angela P. Harris, 1997. Race and Essentialism in Feminist Legal Theory. In Adrien Katherine Wing (ed.), Critical Race Feminism:
} 
as a legal matter, the phenomenon of rape did not even exist for Black women, since during Slavery, the rape of a Black woman by any man, White or Black, was not a crime. This lack of legal protection for Black women against the crime of rape continued because rape laws were seldom invoked to protect Black women since these women were considered to be 'promiscuous' by nature ${ }^{\mathbf{1 6}}$

Harris also notes that for Black people, male and female, "rape signified the terrorism of Black men by White men, aided and abetted, passively (by silence) or actively (by 'crying rape'), by White women." ${ }^{, 17}$ Harris also argues that this aspect of rape is not purely historical and has a contemporary basis. She cites reports by Susan Estrich and others which show that between 1930 and 1967, 89 percent of the men executed for rape in the United States were Black. A 1968 study of rape sentencing in one State showed that in all of the fifty-five cases where the death penalty had been imposed on Black men, the victims had been White, while 47 percent of all Black men convicted of assaults on Black women were released on probation. ${ }^{\mathbf{1 8}}$

Similarly, Paul Kevel notes that "at times, White women's groups have supported attacks against the African-American community in the name of [White] women's safety. In the late nineteenth century the National American Woman's Suffrage Association refused to take a stand against lynching and mob violence...it did not support the organizing of chapters of Black women because it did not want to jeopardize White southern support for White women's right to

A Reader. New York: New York University Press at p. 15, reproduced in Canadian Critical Race Theory: Racism and the Law, Ibid. ${ }^{16}$ Race and Essentialism in Feminist Legal Theory, Supra, note 13 at 16, reproduced in Canadian Critical Race Theory: Racism and the Law, Supra, note 1.

${ }^{17}$ Race and Essentialism in Feminist Legal Theory, Ibid. at 16.

${ }^{18}$ Ibid. at 16 
vote... and they argued that if they (White women) could vote, it would buttress the supremacy of the White race against the demands of Black people."19 Kevel also notes that the disproportionate criminalization and punishment of Black men for violence against White women continues today. ${ }^{\mathbf{2 0}}$ There are many other examples in contemporary feminist legal scholarship where mainstream feminist writers have ignored the issues of race in their analysis of criminal law as well as in other areas of law. If "race" or racism is discussed at all, it is generally done so in passing, as an 'add on' to gender analysis and with no real inquiry in regard to how the law impacts in differing ways on women of colour and White women. ${ }^{21}$ This deficiency, Critical Race feminists argue, is particularly acute in the procedural area of sentencing and disproportionate representation of Black women and other women of colour in the criminal justice system. $^{22}$

With respect to 'intersectionality', and Aboriginal peoples, Aboriginal scholars like Patricia Monture-Angus have written extensively on Canadian law and its ineffectiveness in resolving Aboriginal claims. With respect to Aboriginal women and the law she says:

As a Mohawk woman who came to study Canadian law, I am forever balancing the teaching, rules, and principles of both systems. This balancing act probably leads me to different understandings about the structure and shape of Canadian law.

This is not a visibility that operates solely because I come from a "different" culture. It becomes visible because of both my tradition and gender, realities that operate

\footnotetext{
${ }^{19}$ Paul Kivel, Uprooting Racism: How White People Can Work for Racial Justice. 1996. Gabriola Island, B.C.: New Society Publishers at p. 62 reproduced in Canadian Critical Race Theory: Racism and the Law, Supra, note 1, at 16.

${ }^{20}$ Ibid. at 62

${ }^{21}$ Canadian Critical Race Theory, Supra, note 1 at 38.

${ }^{22}$ Ibid. at 38
}

Volume 1, Number 1, 2010 
concurrently in interlocking ways. ${ }^{23}$

Women with disabilities have also written at great length on intersectionality issues such as disabled women and poverty, disabled women and violence, disabled women and sexual assault law, disability and access, to name a few. ${ }^{\mathbf{2 4}}$ Lesbian women have produced extensive literature on intersectional gender and sexual orientation, class/poverty theory, family status, pornography, race and sexual identity. ${ }^{25}$ And as is apparent from a search of the literature, there is a growing body of feminist literature on the intersection of gender, disability, race, and sexual orientation with class and poverty. ${ }^{\mathbf{2 6}}$ In the ensuing ten years of women's Charter equality rights litigation since the Canadian Advisory Council on the Status of Women made the observation that “... judges are not being presented with women's unique experience of discrimination based on race, social status, disability, age, sexual orientation, marital status, or religion" ${ }^{\text {27 }}$, what arguments have been put forth by LEAF and other equality rights advocates that conceptualize an adequate framework for analysing the intersections of race, class, gender, sexual orientation, and disability? Have these arguments assisted the courts in developing intersectional equality

\footnotetext{
${ }^{23}$ Patricia Monture-Angus, Standing Against Canadian Law: Naming Omissions of Race, Culture, and Gender, 1999, in Locating Law: Race/Class/Gender Connections. Halifax. Fernwood Publishing at 77. See also: Patricia A. Monture-OKanee, 1993. Ka-Nin-GehHeh-Gah-E-Sa-Nonh-Ya-Ga. 6 C.J.W.L. 119 and Mary Ellen Turpel, Patriarchy and Paternalism: The Legacy of the Canadian State for First Nations Women, (1991) 6 C.J.W.L. 174.

${ }^{24}$ Joanne Doucette, Disabled Women and Poverty: Double Oppression (1987), 5 Just Cause 13; Diane Driedger, and April D’Aubin, Discarding the Shroud of Silence: An International Perspective on Violence, Women and Disability (1991), 12, Canadian Women Studies 81. Sandra Goundry, The Double Burden Exponentialized: Women, Disability and the Law (1986) 6 Archtype 4; Dianne Pothier, Equity and Access (1995), 33 Alberta Law Review 817. For an extensive bibliography of the literature on intersecting oppressions see: Josee Bouchard, Susan B. Boyd, and Elizabeth A. Sheehy, Canadian Feminist Literature on Law: An Annotated Bibliography, 1988-1998 (English) and 1980-1998 (French), (1999), 11 No. 1\&2, Canadian Journal of Women and the Law. ${ }^{25}$ See for example: Mary Eaton, Homosexual Unmodified: Speculations on Law's Discourse, Race, and Construction of Sexual Identity, in Legal Inversions: Lesbians, Gay Men and the Politics of the Law, Didi Herman and Carl Stychin eds., 1995. Philadelphia: Temple University Press 46. Also see Bouchard, Boyd, Sheehy Ibid., for an extensive bibliography of lesbian scholarship.

${ }^{26}$ Canadian Feminist Literature on Law: An Annotated Bibliography, Ibid. at 296.

${ }^{27}$ Canadian Advisory Council on the Status of Women, Supra, note 4, at pp.4-5.
} 
principles/jurisprudence? How has the Supreme Court of Canada responded to these arguments?

In this paper I argue that despite the fact that there exists in Canada (at least since the 1980s) "theoretical debates" about "the intersecting nature of race, class, and gender as well as sexual orientation and disability", ${ }^{28}$ scholarship on intersectionality theory has been largely ignored by the Canadian judiciary including, in large part, by the Supreme Court of Canada. Similarly, while feminist advocates like LEAF have made some inroads, much work is still required in order to conceptualize a framework for analysing the intersections of race, class, gender, sexual orientation, and disability that will assist the courts in developing intersectional equality jurisprudence.

\section{'Intersectionality': Definitional Problems}

Racism and sexism are interlocking, mutually reinforcing components of a system of dominance rooted in patriarchy. No significant and lasting progress in combating either can be made until this interdependence is acknowledged, and until the perspectives gained from considering their interaction are reflected in legal theory and public policy. ,29

What exactly do theorists mean when they talk about the principle of intersectionality?

The first analysis of 'intersectionality' in the context of race/sex and class oppression was put

\footnotetext{
${ }^{28}$ See Elizabeth Cumack et al, eds. "Locating Law: Race/Class/Gender Connections”, 1999. Halifax: Fernwood Publishing. See also Nitya Duclos, "Disappearing Women: Racial Minority Women in Human Rights Cases" (1993) 6 C.J.W.L.25; Nitya Iyer, Categorical Denial: Equality Rights and the Shaping of Social Identity", (1993), 19 Queen's L.J. 179; Sherene Razack, "Looking White People in the Eye: Gender, Race, and Culture in Courtrooms and Classrooms. 1998. Toronto: University of Toronto Press; Mary Eaton, "Patently Confused: Complex Inequality and Canada v. Mossop", (1994) 1 Rev. Cons. Stud. 203; Carl F. Stychin, "Essential Rights and Contested Identities: Sexual Orientation and Equality Rights Jurisprudence in Canada", (1995), 8 Cdn. J. Law and Jur. 49; see also the growing literature on the intersectionality of disability, class/poverty and sexual orientation in Canadian Feminist Literature on Law: An Annotated Bibliography, Supra, note 22.

${ }^{29}$ Paulette M. Caldwell, A Hair Piece: Perspectives on the Intersection of Race and Gender, in Richard Delgado, eds., 1995. Critical Race Theory: The Cutting Edge. Philadelphia: Temple University Press at 267.
} 
forward by American Critical Race theorist Kimberle Crenshaw ${ }^{30}$. Crenshaw examined how sex, race and class combine to oppress Black women and other women of colour in a social order based on race and sex oppression.

Mary Eaton, crediting Crenshaw with the 'coining' of the phrase intersectionality, defines it as "intersectional oppression [that] arises out of the combination of various oppressions which, together, produce something unique and distinct from any one form of discrimination standing alone...”31 There has been however, a great deal of theoretical and judicial confusion (quite apart from the resistance to the concept itself) that has proliferated the discourse on this subject. For example, Mary Eaton in her article "Patently Confused: Complex Inequality and Canada v. Mossop ${ }^{\mathbf{3 2}}$ points out the existence of this confusion in Supreme Court of Canada analysis of multiple discrimination in the Mossop ${ }^{33}$ case. In particular she highlights the judicial confusion regarding the concepts of intersectionality, compound discrimination, and overlapping discrimination.

Mossop $^{\mathbf{3 4}}$ was a case involving a Charter challenge to the failure of the Canadian Human Rights Act to protect lesbian and gay couples against discrimination under the ground of family status in the Act. Eaton in her analysis notes that:

... a close reading of Mossop unfortunately reveals that at the level of both legal theory and practical application, the Court betrayed a profound misunderstanding

\footnotetext{
${ }^{30}$ Kimberle Crenshaw, Demarginalizing the Intersection of Race and Sex: A Black Feminist Critique of Antidiscrimination Doctrine, Feminist Theory and Antiracist Politics [1988-89] U. Chi. Nlegal F. 139.

${ }^{31}$ Patently Confused, Supra, note 26, at 229.

${ }^{32}$ Patently Confused: Supra, note 26, at 229-30.

${ }^{33}$ Canada v. Mossop, [1993] 1 S.C.R. 554.

${ }^{34}$ Canada v. Mossop, Ibid.
} 
of the problem it sought to redress, perhaps confounding future efforts to refashion anti-discrimination law to better respond to problems of complex inequality. $^{35}$

Particularly pertinent to the current discussion is Eaton's observation that members of the Court had "...muddied the conceptual waters by failing to draw the necessary distinctions between overlapping, compound and intersecting oppressions., ${ }^{\mathbf{3 6}}$ So what are the distinctions between overlapping, compound and intersecting oppressions discussed by Eaton and why do they matter? In order to understand the concepts of overlapping, compound and intersecting oppressions and the differences between them it is first necessary to look at the dominating principle in Charter equality (s.15) jurisprudence that informs the way discrimination claims have developed in the law. That dominating principle flows from the 'enumerated grounds' or 'analogous grounds' approach taken by the Supreme Court of Canada to s.15 equality claims. The Canadian Charter of Rights and Freedoms s.15 states that:

Every individual is equal before and under the law and has the right to the equal protection and equal benefit of the law without discrimination and, in particular, without discrimination based on race, national or ethnic origin, colour, religion, sex, age or mental or physical disability. ${ }^{37}$

The first case to deal with an interpretation of the equality guarantee in s.15 of the Charter was Andrews ${ }^{\mathbf{3 8}}$ The Supreme Court of Canada interpreted the s.15 purpose as that of promoting "a society in which all are secure in the knowledge that they are recognized at law as

\footnotetext{
${ }^{35}$ Patently Confused: Ibid. at 229

${ }^{36}$ Patently Confused, Ibid. at 235

${ }^{37}$ Charter, s.15, Supra, note 3

${ }^{38}$ Andrews v. Law Society of British Columbia, [1989] 1 S.C.R. 143.
} 
human beings deserving of concern, respect and consideration." ${ }^{\mathbf{3 9}}$ Further, the Supreme Court of Canada says that the purpose of s.15 is "to remedy or prevent discrimination against groups subject to stereotyping, historic disadvantage and political and social prejudice.",40

The most recent Supreme Court of Canada pronouncement on the purpose of s.15 equality provision can be found in the $1999 \mathrm{Law}^{\mathbf{4 1}}$ case. Iacobucci J., delivering the judgement of the Court, states that "...a focus is quite properly placed upon the goal of assuring human dignity by the remedying of discriminatory treatment.",42 The 'enumerated' or 'analogous' grounds approach to a determination of discrimination under s.15 was also adopted from the Andrews $^{\mathbf{4 3}}$ case. In Andrews, McIntyre J., speaking for the Court, held that discrimination in s.15 was to be determined only on the distinctions listed in s.15 or on comparable grounds:

This enumerated and analogous grounds approach most closely accords with the purposes of s.15 and leaves questions of justifications to s.1. ${ }^{\mathbf{4 4}}$

\footnotetext{
${ }^{39}$ Andrews, Ibid. per McIntyre J. at 171.

${ }^{40}$ Andrews, Ibid. per McIntyre J. at 180-181. The purposes of s.15 which were set out in Andrews were supported in subsequent cases and reiterated in the case of Law v. Canada, [1999] 1 S.C.R. 497 at 526. The Law case involved a Charter challenge to the provisions of the Canada Pension Plan which denied benefits to able-bodied survivors under the age of 45 and without dependent children. The issue was whether the denial of benefits to Nancy Law amounted to discrimination on the basis of age pursuant to s.15. The Supreme Court of Canada dismissed the appeal finding no infringement of s.15.

${ }^{41}$ Law, Supra, note 38, at 530.

${ }^{42}$ Law, Ibid. at 530

${ }^{43}$ Andrews, Supra note 36, at 182.

${ }^{44}$ Andrews, Ibid. at 182. See also: Peter W. Hogg, Constitutional Law Of Canada, 1992. Toronto: Carswell Thomson Professional Publishing. Hogg points to R. v. Turpin, [1989] 1 S.C.R. 1296, at 1332, where “... Wilson J. for a unanimous Court approved the "enumerated and analogous grounds approach"; R. v. Swain, [1990] 1 S.C.R. 933, at 992, where "Lamer C.J. with the agreement of Sopinka and Cory JJ., also approved the "enumerated and analogous grounds approach"; and R. v. Genereus [1992] 1 S.C.R. 259, 311, where "Lamer C.J. approved the restriction to analogous grounds"; and Miron v. Trudel [1995] 2 S.C.R. 418, and Egan v. Canada [1995] 2 S.C.R. 513, where "eight of the nine judges accepted the restriction to analogous grounds [and] only L'Heureaux-Dubé J. rejected that interpretation of s.15." Additionally, in the recent Supreme Court of Canada Law case, Iacobucci J., also re-affirmed the grounds approach to s.15 (1) analysis: As ...McIntyre J. Emphasized in Andrews ...the guarantee [in s.15] is a comparative concept. Ultimately, a court must identify differential treatment as compared to one or more other persons or groups...The object of a s.15 (1) analysis is not to determine equality in the abstract; it is to determine whether the impugned legislation creates differential treatment between the claimant and others on the basis of enumerated or analogous grounds, which results in discrimination [emphasis in original]. Law, Supra, note 38, at p. 531.
} 
Because this restrictive interpretation of $\mathrm{s} .15$ requires the complainant to base her claim of discrimination on a single ground or more than one single ground of discrimination, as though they were mutually exclusive, it has been argued that the 'enumerated' or 'analogous' grounds approach adopted by the Supreme Court in s.15 interpretation is analytically unsound. This is so because it fails to accommodate multiple sites of oppression and because it excludes from s.15 protection those who are not included in the 'enumerated' grounds or cannot bring themselves within an 'analogous' ground. ${ }^{45}$ Adding to the problem of the 'enumerated' or 'analogous' ground approach to s.15 interpretation is the failure of mainstream feminist theory and advocacy (until recently) to put forth a theory of sex discrimination that did not have at its centre White, able-bodied, middle-class, heterosexual women ${ }^{46}$. As well there has been an on-going failure of women's advocacy organizations such as LEAF to conceptualize an analytical framework focusing on the intersections of race, class, disability, gender, and sexual orientation that will assist the courts in developing intersectional equality jurisprudence. However, in order to

\footnotetext{
${ }^{45}$ For a discussion of the problems with the 'enumerated' or 'analogous' grounds interpretative approach to s.15 See: Nitya Iyer, Categorical Denials: Equality Rights and the Shaping of Social Identity (1993) 19 Queens L.J. 179. Mary Eaton, Patently Confused: Complex Inequality and Canada v. Mossop (1994) 1 Rev. Cons. Stud. 203.; Nitya Duclos, Disappearing Women: Racial Minority Women in Human Rights Cases, (1993) 6 C.J.W.L. 25; Mary Eaton, At the Intersection of Gender and Sexual Orientation: Toward Lesbian Jurisprudence, (1994) 3 So. Cal. Rev. L. \& Women's Stud. 183; C. Littleton, Double and Nothing: Lesbian as Category, (1996) 7 UCLA Women's L.J. 1; Dianne Pothier, Charter Challenge to under inclusive Legislation: The Complexities of Sins of Omission, (1993) 19 Queen's L.J. 261. For a bibliography of scholarship on this topic See: Josee Bouchard, Susan B. Boyd, and Elizabeth A. Sheehy, Canadian Feminist Literature on Law: Supra, note 22.

${ }^{46}$ The critique of mainstream feminism canters around the 'essentialist' nature of mainstream feminist theory. The critics point out that "white feminist theorists, while powerful and brilliant in many ways, nevertheless base many of their insights on gender essentialism-the idea that women have a single, unitary nature. They point out that certain feminist scholars write as though women's experiences can be captured in general terms, without taking into account differences of race or class. Richard Delgado, Rodrigo's Sixth Chronicle: Intersections, Essences, and the Dilemma of Social Reform, in Critical Race Theory: The Cutting Edge 1995. Philadelphia: Temple University Press at 242. See also Mari J. Matsuda, When the First Quail Calls: Multiple Consciousness as Jurisprudential Method, (1989) 11 Womens Rts. L. Rep. 7, 9; Angela P. Harris, Race and Essentialism in Feminist Legal Theory, (1990) 42 Stan. L. Rev. 581. Emily Carasco, A Case of Double Jeopardy: Race and Gender, (1993) 6 C.J.W.L. 142; Marlee Kline, Race, Racism, and Feminist Legal Theory, (1989) 12 Harv. Women's L. J. 155; Mari Matsuda, Where is Your Body? And Other Essays on Race, Gender, and the Law, (1996) Boston: Beacon Press.
} 
conceptualize a framework for analysing the intersections discussed above and presenting these arguments before the courts, a better grasp of the concepts of intersectionality, and compound and overlapping discrimination and the distinctions between them is required. An analytical framework for analysing intersectional and compound discriminations is even more pressing given the recent pronouncement by the Supreme Court of Canada in the $2 a w^{47}$ case. Iacobucci J. held that:

A discrimination claim positing an intersection of grounds can be understood as analogous to, or as a synthesis of, the grounds listed in s.15(1). If the CPP had based entitlement on a combination of factors, the appellant would still have been able to establish the requisite distinction, whether on the basis of age alone, or based on a combination of grounds. ${ }^{48}$ [Emphasis added].

I believe that it can be inferred from this statement, and from the Court's recognition that "It goes without saying that as our s.15 jurisprudence evolves it may well be that further elaborations and modifications will emerge", 49 that the Court is attempting to move away from the limiting and unfair 'watertight compartments" or 'single-axis' analysis approach to s.15. ${ }^{\mathbf{5 0}}$ It will be the responsibility of women's rights advocacy organizations like LEAF, and others, to further move the Court in this direction. The Court's pronouncement that claims of intersectional discrimination grounds are 'analogous' grounds to those listed in s.15(1) has, in my view, given us the long awaited tool with which to pursue a better analytical structure for

\footnotetext{
${ }^{47}$ Law, Supra note 38 .

${ }^{48}$ Law, Ibid. at 503 .

${ }^{49}$ Law, Supra, note 38, at 548 .

${ }^{50}$ Generally for a discussion of the concepts of "watertight" or "single-axis" analysis See: Mary Eaton, Patently Confused: Complex Inequality and Canada v. Mossop, (1994) 1 Rev. Cons. Stud. 203; Vriend v. Alberta, [1998] 1 S.C.R. 493, Factum of the Intervenor Women's Legal Education and Action Fund (LEAF); and Nitia Iyer, Disappearing Women: Racial Minority Women in Human Rights Cases, (1993) C.J.W.L. 25.
} 
multiple discrimination claims. While the Supreme Court of Canada seems unwilling to reject altogether the concept of 'enumerated' and 'analogous' grounds, it has moved one step further away from what has been referred to as the 'watertight compartments' approach to discrimination. ${ }^{\mathbf{5 1}}$

Capitalizing on this judicial move forward, theorists and feminist advocacy organizations, must, in my view, aggressively present to the Court a clear analytical framework that demonstrates what an intersection of grounds as an analogous ground means as a concept, and how this concept should be applied by the courts. In order to do this two things are required. First, mainstream feminists must abandon the belief that arguing intersectionality before the courts will somehow fracture feminist legal goals. Second, feminists from the dominant group must abandon their predisposition to see race, class, disability and sexual orientation, simply as 'add-ons' to discrimination based on sex and the assumption that gender discrimination is oppressive in the same way for all women, only more so for 'racialized women', 'disabled women', 'poor women' and 'lesbian women', thereby leaving intact the unstated 'norm' of whiteness, heterosexuality, and able- bodiness.

Before we can advance a theoretical framework of multiple discrimination (intersectional, compound and overlapping) that will assist the Supreme Court of Canada in expanding and advancing its partial analysis in the Law case, a re-statement of definitions based on the foregoing analysis is in order. The following definitions based on the available literature

\footnotetext{
${ }^{51}$ For an example of an argument against a "watertight" compartments approach to discrimination advanced by LEAF See: Vriend $v$. The Queen, Factum of the Intervenor Women's Legal Education and Action Fund (LEAF) Para. 25 on file with the Author.
} 
by authors like Crenshaw and Eaton may assist in clearing up the Courts (and our own) confusion regarding the terms used to depict multiple sites of discrimination. The definitions that follow essentially use the language of Eaton and others who have written on this subject, with commentary regarding their relevancy to future s. 15(1) equality analysis.

\section{“Overlapping" Grounds Discrimination}

Overlapping grounds have been described as the basing of a discrimination claim on two or more grounds (where a finding of discrimination could be found on both grounds e.g. race and age discrimination) and making a determination (as a matter of strategy) as to where the evidentiary emphasis will be placed. Overlapping grounds are not distinct grounds in the sense that intersectionality grounds are distinct nor do they constitute a "double whammy" or an "addon" in the sense that compound discrimination claims do. In my view, while they do not inherently require 'either' 'or' strategy (i.e. the finding of discrimination is based on one single ground mutually exclusive of the other(s)), overlapping grounds commonly lead to the making of a strategic choice by litigators as to where the 'evidentiary' focus will be placed quite often based on the uncomplicated nature of the ground. In cases of gender and race for example, it is unlikely that both grounds will be argued with equal emphasis. The concept of overlapping discrimination does not, in my view, advance us very far in that discrimination based on race for example, will often not be the ground on which evidentiary focus will be placed because generally speaking there is an unwillingness or an inability of many White practitioners to make 
racial arguments before the Courts. This unwillingness or inability may stem from a number of factors such as conscious or unconscious racism, an inability to recognize the racial implications of a particular case, a lack of knowledge about how to challenge and deconstruct legal rules and principles which foster and maintain discrimination based on race, total acceptance of the myth of the "objectivity" of laws, or fear that raising issues of race before the courts will disadvantage a client's case because of the court's unacceptance towards these arguments. ${ }^{\mathbf{5 2}}$ The 'overlapping grounds' approach will continue to force women who face multiple sites of oppression to 'bifurcate' themselves for 'strategic' purposes. It will also allow advocates and courts to address only those forms of discrimination they are most comfortable with, by avoiding claims of racism, for example

\section{"Intersectional" Grounds of Discrimination}

Intersectionality has been described as the ability of Black women, Aboriginal women, other women of colour, women with disabilities, lesbian women, or poor women, to base a claim of discrimination under s.15 of the Charter as a distinct group of women who are subject to a form of discrimination quite apart from that experienced (in the case of Black women) by Black men and White (and other women) regardless of colour. The form of discrimination experienced by Black women is not related to some "immutable" characteristic(s) inherent in Black women

\footnotetext{
${ }^{52}$ For a detailed discussion of these concepts see: Canadian Critical Race Theory: Supra, note 1.
} 
(skin colour for example), but rather, it is a form of discrimination arising because of society's stereotyping of Black women and its historical treatment of them. Intersectionality analysis in the case of women with disabilities would found a claim of discrimination that is distinct from that faced by able-bodied women and disabled men. Likewise, intersectional discrimination for lesbian women would mean a claim of discrimination distinct from that faced by heterosexual women and gay men and a class/poverty intersectionality analysis would found a claim of discrimination distinct from those made by economically advantaged women. Intersectionality claims of discrimination may include one or more of the enumerated grounds of discrimination set out in s.15 of the Charter or analogous grounds and, pursuant to the Law case, such intersectional claims are themselves an 'analogous' ground of discrimination.

\section{“Compound" Grounds Discrimination}

Compound discrimination may be experienced by all members of the group as well as by White heterosexual able-bodied women. For example, discrimination based on race may be experienced by both racialized men and women and White women. In the case of discrimination based on disability, the discrimination may be experienced by both disabled men and women and White women, and discrimination based on sexual orientation may be experienced by both lesbian women and gay men as well as White heterosexual women. However, the particular discrimination will be intensified (or be an 'added' burden) for the racialized, disabled, lesbian or 
poor woman. Claims of compound discrimination have also been recognized in the $L a w^{53}$ case and women's rights advocacy organizations such as LEAF have regularly made 'add-on' arguments in facta before the courts. As noted above, 'add-on' arguments, while addressing compound forms of discrimination, tend to leave the unstated 'norm' of the White, heterosexual, able-bodied, middle-class woman intact and does not question the underlying white supremacist, able-bodied or heterosexual notions attached to this 'norm'.

The Supreme Court of Canada decision in $R$. v. Mossop ${ }^{\mathbf{5 4}}$ reflects the analytical confusion regarding the various forms of multiple discrimination displayed by advocates appearing before it. Mr. Mossop, who was in a relationship with another man, attended the funeral of his partner's father. He was denied bereavement leave under his collective agreement because it did not allow bereavement leave to same sex employees. Mr. Mossop filed a discrimination complaint with the Canadian Human Rights Commission on the basis of family status. The issue in the case was whether the term "family status" in the Canadian Human Rights Act ${ }^{55}$ included a homosexual relationship (at the time of this case the Act had not yet been amended to include sexual orientation as a prohibited ground of discrimination). ${ }^{\mathbf{5 6}}$ The Human Rights Tribunal found that the denial of bereavement leave was discriminatory based on "family status". This decision was

\footnotetext{
${ }^{53}$ Law, Supra, note 38 .

${ }^{54}$ Mossop, Supra, note 31.

${ }^{55}$ Canadian Human Rights Act, R.S.C. 1985, c. H-6, s.3-1.

${ }^{56}$ Shortly after the Federal Court heard the Mossop appeal the Ontario Court of Appeal in Haig v. Canada (1992), 9 O.R. (3d) 495 added sexual orientation to the list of prohibited grounds of discrimination contained in s.3 of the Canadian Human Rights Act. Mr. Mossop based his claim of discrimination on "family status" and not on "sexual orientation" because sexual orientation was not an enumerated ground of discrimination contained in the Act. He did not amend his appeal subsequent to the decision in the Haig case to challenge the constitutionality of s.3 of the Canadian Human Rights Act. Lamer C.J., in the majority decision of the Supreme Court of Canada criticised this approach which he said forced the Court to decide the issue solely on the determination of the meaning of family status.
} 
Intersectionality

AYLWARD

appealed to the Federal Court of Appeal which overturned the Human Rights Tribunal's decision and held that "family status" in the Human Rights Act did not include same sex relationships.

The decision of the Federal Court of Appeal was further appealed to the Supreme Court of

Canada. The Majority of the Supreme Court dismissed the appeal and held that the denial of

bereavement leave did not constitute discrimination based on "family status"

L'Heureaux-Dubé, Cory and McLachlin JJ dissented. Both the Majority and the

dissenting Justices refer to “overlapping” grounds of discrimination as well L’Heureaux-Dubé J. also refers to "intersecting” grounds of discrimination." for the Majority, simply mentions “overlapping grounds of discrimination” without deeper analysis and denies Mossop's claim based on the fact that "family status" did not include same sex couples and "sexual orientation" was not a prohibited ground of discrimination under the Act. This conclusion ignores the fact that the concept of "overlapping" grounds of

\footnotetext{
${ }^{57}$ Mossop, Supra, note 31 at p.645. L'Heureaux-Dubé stated that "The Attorney General ....argued that the Tribunal erred in finding discrimination on the basis of "family status", rather than based on sexual orientation, a ground not found in s.3 of the Act...in a ruling of the Ontario Court of Appeal in Haig v. Canada (1992), 9 O.R. (3rd) 495 (rendered after this case was heard)...s.3 of the Act was found to include "sexual orientation" as a ground of discrimination. However, the parties have agreed that this case be dealt with on the basis of the Act as it read when this case was brought before this Court. In light of this, the Chief Justice adopts the position that the discrimination in this case is one of sexual orientation. This line of reasoning implies that any disadvantage that may accrue to same-sex partners is inextricably linked to their sexual orientation, that the denial of the benefit thus amounts to sexual orientation discrimination and, as the Act did not then prohibit discrimination on the basis of sexual orientation, that it was not a matter properly before the Tribunal. This argument is based on an underlying assumption that the grounds of "family status" and "sexual orientation" are mutually exclusive. However, categories of discrimination often overlap in significant measure. In this instance, the Tribunal found that Mr. Mossop suffered discrimination on the basis of "family status", not on the basis of his sexual orientation. However, the argument that this is more properly seen as sexual orientation discrimination raises an important question which in some cases, though not here in my view, may be determinative of the scope of human rights protection. It is increasingly recognized that categories of discrimination may overlap, and that individuals may suffer historical exclusion on the basis of both race and gender, age and physical handicap, or some other combination. The situation of individuals who confront multiple grounds of disadvantage is particularly complex...Categorizing such discrimination as primarily racial orientated, or primarily gender-orientated, misconceives the reality of discrimination as it is experienced by individuals. Discrimination may be experienced on many grounds, and where this is the case, it is not really meaningful to assert that it is one or the other. It may be more realistic to recognize that both forms of discrimination may be present and intersect. On a practical level, where both forms of discrimination are prohibited, one can ignore the complexity of the interaction, and characterize the discrimination as of one type or the other. The person is protected from discrimination in either event. This analysis by L'Heureaux-Dubé however, is problematic because it fails to recognize that this 'complexity' is in fact the very problem which must be addressed.
} 
discrimination means that Mossop's claim could have been supported in either ground of discrimination. With respect to "overlapping" grounds of discrimination the Chief Justice simply concludes, without more, that "...the hypothesis of overlapping grounds of discrimination should [not] be ruled out in other contexts." In response to Lamer C.J.'s failure to grant Mossop relief based on overlapping grounds of discrimination Mary Eaton observes that L'Heureaux-Dubé J., ...is quite right when she points out that simply because one construction of an overlapping claim has not been statutorily enacted does not mean that an equally valid but alternative construction of the discrimination in issue which is covered by statute must be read down to exclude coverage for those claims which might also be conceptualized as falling within the parameters of the unlegislated ground."

However, L’Heureaux-Dubé J.'s own analysis of “overlapping” and “intersecting” grounds of discrimination is also confusing and leads her to wrongly conclude that in the case of multiple grounds of discrimination where "both forms of discrimination are prohibited, one can ignore the complexity of the interaction and characterize the discrimination as of one type or the other. The person is protected from discrimination in either event." the Court's comprehension of the various forms of discrimination led to a wrong decision in the Mossop case.

In her analysis of the Supreme Court of Canada's confusion with regard to the various types of multiple discrimination displayed in the Mossop case, Eaton observed that the Supreme Court majority attempted to:

...forge a new analytic for addressing complex equality claims. Specifically, the majority seems to have signalled that it is prepared to abandon the so-called

\footnotetext{
${ }^{58}$ Mossop, Supra, note 31 at 645.
} 
'water-tight compartments' approach to human rights interpretation...,59

However, Eaton, while recognizing that the Court's move away from the 'watertight compartments' approach was to be celebrated, noted that the Court did not seem to understand the problem of multiple discrimination presented to it. ${ }^{\mathbf{6 0}}$

Specifically, Eaton points out that both Lamer C.J., and L'Heureaux-Dubé J., use the terms 'overlapping' as well as 'intersecting' to describe multiple discrimination which the "principle of mutual exclusivity of grounds fails to accommodate." 61 Eaton notes that use of this language without an understanding of its implications by the Court is not without consequences. She points out that scholarship on this issue is clear that "the concepts of overlapping or intersecting oppressions...are really quite distinct." ${ }^{\mathbf{6 2}}$ Eaton then goes on to explain the differences between them.

As noted above, Intersectional discrimination is a "unique" and "distinct" form of discrimination which stands alone and results from a combination of grounds such as gender, race, class, disability, and sexual orientation and so on. ${ }^{63}$ Eaton attributes the evolution of intersectional analysis to racialized women who criticised mainstream feminist analysis which "wrongly assumed that race only made sex-discrimination matters worse, as opposed to different, for women of colour." ${ }^{\mathbf{6 4}}$ With respect to Compound discrimination, Eaton points out that this is

\footnotetext{
${ }^{59}$ Patently Confused: Supra, note 26 at p. 206.

${ }^{60}$ Patently Confused: Supra, note 26 at 228-229.

${ }^{61}$ Patently Confused: Ibid. at 229

${ }^{62}$ Patently Confused: Ibid. at 229

${ }^{63}$ Patently Confused: Ibid. at 229

${ }^{64}$ Patently Confused: Ibid. at 230-231
} 
in fact a very different situation. In these cases: “...race might compound sex inequality, or sex might compound race inequality, that is, where these (and perhaps other) systems of oppression [do] combine to produce an additive burden. ${ }^{\mathbf{6 5}}$ [Emphasis added].

Here, the difference between intersectional discrimination and Compound discrimination is that in an intersectional discrimination case, the discrimination is distinct in that it is based on (in the case of Black women) society's stereotyping and historical treatment of Black women.

The discrimination experienced will not be experienced by Black men or by White (or even all) women regardless of race. On the other hand, in the case of compound discrimination the discrimination will be experienced by Black men and White (and other) women regardless of race only it will be intensified (or present an added burden) for the Black woman.

Likewise, in the case of women with disabilities, intersectional discrimination will be distinct in that it is experienced only by women with disabilities (not men with disabilities or all women). Compound discrimination in this case would be experienced by disabled men and all women but intensified for disabled women. In the case of lesbians, intersectional discrimination will be distinct in that it will not be experienced by gay men or all women. Compound discrimination in this case would be experienced by gay men and all women but intensified for lesbian women.

Eaton gives as an example of compound discrimination a police recruitment policy which has both a written test that systemically excludes Black people and a height requirement that

\footnotetext{
${ }^{65}$ Patently Confused: Supra, note 31 at 231.
} 
systemically excludes most women. Eaton points out that "in combination, the two screens compound the discriminatory exclusion of black women from the workplace." ${ }^{\mathbf{6 6}}$ This compound discrimination would occur both because the candidate is Black and both Black men and women would be excluded and because the candidate is a women and the height policy would include many women regardless of race. Thus, the odds would be greater that a Black woman would be excluded on one or the other of these two grounds, then that Black men or White women would be excluded, because the latter groups are only at risk from one of the two policies. Conversely the candidate would be subject to discrimination on intersectional grounds if the police policy affected only Black women. Eaton then goes on to describe what she terms "overlapping oppression" which she notes has not been addressed in the academic literature. 'Overlapping' oppression Eaton characterizes as discrimination that can be litigated on two or more grounds. In defining this type of discrimination she gives the example of an Aboriginal man with a criminal record who has been denied a job. Eaton argues that the case could be litigated on either the basis of race or on the basis of criminal record. She contends that if the complaint is brought on the basis of criminal record no contextual analysis is required.

The issue is straightforward because the treatment of the individual Aboriginal man would not have differed from that accorded all convicted persons or all Aboriginal people. ${ }^{67}$ Eaton argues that if the complaint is based on the 'clean record' rule (an employee is required to have no criminal record) no 'contextual' analysis is required. I would however, disagree with her

${ }^{66}$ Patently Confused: Supra, note 26, at 231.

${ }^{67}$ Patently Confused: Ibid. at 231 
analysis that no contextual analysis would be required in this situation. A Critical Race Theory approach for example, would require that a 'race-conscious' approach be taken with respect to the apparently 'neutral' on its face 'clean record' rule. Critical Race Theory requires us to contextualize the problem and to deconstruct what appear to be 'neutral' laws by locating the problem within the social reality of racism. ${ }^{\mathbf{6 8}}$ Eaton goes on to argue however, that a contextualized analysis would be required only if the complaint is based on race. In this case, Eaton argues that the complaint would have to be substantiated by a:

Contextual, statistical analysis of the disproportionate criminalization and incarceration of Canada's first peoples. Such a disparate impact analysis could reveal the racial dimensions of the 'clean record' rule and, absent adequate business justification, could call for the rule to be struck as discriminatory. Although the discrimination experienced by the job applicant could be legally formulated in either of two ways, it does not follow that the denial of employment was experienced as a "double whammy" in the compound discrimination sense, or as a unique thing, in the intersectional discrimination sense, wholly distinct from the experience of convicted offenders or First Nations people in general. ${ }^{69}$

In the Mossop ${ }^{70}$ case, Eaton concludes that the type of discrimination suffered by the complainant was "overlapping" in that he should have been able to establish his claim as either "family status" or "sexual orientation" depending on whichever of the grounds he preferred. Eaton argues that because of the Court's failure to distinguish between the three forms of multiple discrimination (intersectional, compound, and overlapping):

...more than symbolic damage is done by reducing an account of "what happened" to unidimensional terms ... Law is spared having to engage with the very real injuries of

\footnotetext{
${ }^{68}$ Canadian Critical Race Theory: Supra, note 1, at 139.

${ }^{69}$ Patently Confused: Supra, note 26 at 232.

${ }^{70}$ Mossop, Supra, note 31.
} 
interactive inequalities as they are experienced by multiply oppressed people.",71

However the question of 'overlap' that Eaton is concerned with in her article is, I believe, now less relevant then at the time Eaton wrote. The Supreme Court in the $\mathrm{Law}^{72}$ case, while recognizing that the Andrews ${ }^{73}$ case spoke of differential treatment being based on only one enumerated or analogous ground, has nonetheless, following on the Symes $^{74}$ decision, upheld the proposition that:

it is now open to a s.15(1) claimant to articulate a discrimination claim on the basis of more than one ground...the claimant may place the evidentiary focus of the claim upon a person or subgroup identified by several grounds ${ }^{\mathbf{7 5}}$

The remaining and very real concern with regard to 'overlapping' grounds analysis, as discussed above, is that the claimant will be forced to make strategic decisions regarding where to place the 'evidentiary focus' of the claim. This in turn may result in advocates 'erasing' race from the litigation agenda because other grounds of discrimination may be more 'palatable'( a bias already raised by racialized groups). ${ }^{76}$ Or advocates may continue to address the multiple oppressions of race, disability, lesbianism, and class, as merely 'add-ons' to gender discrimination analysis.

This strategic conundrum can however, be avoided if it is remembered that, in spite of the confusion evidenced by the Supreme Court regarding multiple sites of oppression (as identified

\footnotetext{
${ }^{71}$ Patently Confused: Supra, note 26, at 233.

${ }^{72}$ Law, Supra, note 38.

${ }^{73}$ Andrews, Supra, note 36.

${ }^{74}$ Symes v. Canada, [1993] 4 S.C.R. 358.

${ }^{75}$ Law, Ibid. at p. 523 citing Symes, Ibid.

${ }^{76}$ For a discussion of the 'erasure' of race from the litigation agenda see: Canadian Critical Race Theory, Supra, note 1.
} 
by Mary Eaton in the Mossop case), arguably, the Supreme Court of Canada has been more creative in its recognition of intersectional and compound discrimination as 'analogous' grounds of discrimination under s.15.

\section{Women's Rights Advocacy on Intersectionality Before the Supreme Court of Canada in the Last Ten Years}

...there has been a conscious effort made from the very beginning [by feminists working in law] to prioritize cases that involve double and triple "disadvantage" as is evident in the case selection criteria of the Women's Legal Education and Action Fund $(L E A F)$,... what has been clear, however, is that the methodology employed to expose male domination in these instances has contained a major paradox: If male domination is the prism through which gender oppression is viewed, race and class enter the picture as background scenery. Concealed in the picture is the notion that all women share a core of gender oppression on to which might be grafted additional oppressions. ${ }^{77}$

In her 1991 article Speaking for Ourselves: Feminist Jurisprudence and Minority

Women $^{78}$ Sherene Razack argues that mainstream feminist theorists/advocates have made attempts to be 'inclusive' in both their theory and practice, but in doing so they have succumbed to the temptation to place White women at the centre of their analysis and to reduce workload by merely "adding on layers of oppression by grafting racism on to sexism, as understood by white women." This is what Razack and others call "additive analysis."79 Razack also argues that this "analytical model" was adopted primarily because mainstream middle-class feminists have

\footnotetext{
${ }^{77}$ Sherene Razack, Speaking For Ourselves: Feminist Jurisprudence and Minority Women, (1991) 4 C.J.W.L. 440 at 441. ${ }^{78}$ Speaking For Ourselves: Supra, note 72 at 442.

${ }^{79}$ Speaking For Ourselves: Ibid. at 454. See also: Douglas Kropp, 'Categorial' Failure: Canada's Equality Jurisprudence - Changing Notions of Identity and the Legal Subject, (1997) 23 Queen's L.J. 201 at 207 in which Kropp states: "White feminists often treated gender as the primary basis of discrimination and viewed race as merely increasing the hardship wrought by the gender discrimination."
} 
generally been the ones who have been "applying feminism to law". ${ }^{80}$ Razack supports her thesis by considering two cases taken by LEAF (Tomen v. The Federation of Women Teachers of Ontario and Janzen v. Platy) ${ }^{81}$. The conclusion she draws based on these cases is that LEAF had failed to formulate a theory of multiple oppression and developed instead an 'add-on' theory of multiple oppression at the expense of racialized and other multiply disadvantaged women.

How true is Razack's observation today? Based on the LEAF facta presented to the Supreme Court of Canada in the last ten years (to 1996) ${ }^{\mathbf{8 2}}$ which include 23 presentations, I believe that with a few notable exceptions (discussed below) Razack's observations about the “additive analysis' approach to multiple oppressions taken by LEAF in the early years is still accurate and largely remains intact. For example, in sexual assault cases (Seaboyer ${ }^{\mathbf{8 3}}$, Norberg $^{84}$, M.L.M. ${ }^{85}$, Canadian Newspaper ${ }^{86}$, M.(K) v.M. $(H)^{87} ;$ Whitley $^{88}$ ) a pornography case $(\text { Butler })^{89}$, a women's economic disadvantage case $(\text { Moge })^{90}$; a maternity benefits case $(\text { Schachter })^{\mathbf{9 1}}$, an abortion case ( Daigle $)^{\mathbf{9 2}}$, a midwifery case (Sullivan $)^{\mathbf{9 3}}$, an employment case (Conway $^{94}$, and a refugee case (Canadian Council of Churches) $)^{95}$; multiple oppressions are

\footnotetext{
${ }^{80}$ Speaking For Ourselves: Ibid. at 442.

81 (1987), 61 O.R. (2d) 489; [1989] 1 S.C.R. 1252.

${ }^{82}$ Equality and the Charter: Supra, note 7.

${ }^{83}$ R. v. Seaboyer, [1991] 2 S.C.R. 577. LEAF Factum in Equality and the Charter: Ibid.

${ }^{84}$ Norberg v. Wynrib [1992] 2 S.C.R. 226. LEAF Factum in Equality and the Charter: Ibid.

${ }^{85}$ R. v. M.L.M. [1994] 2 S.C.C. 3. LEAF Factum in Equality and the Charter: Ibid.

${ }^{86}$ Canadian Newspapers Co. v. Canada (Attorney General), [1988] 2. S.C.R. 122. LEAF Factum in Equality and the Charter: Ibid.

${ }^{87} M .(K)$ v. $M(H)$., [1992] 3 S.C.R. 3. LEAF Factum in Equality and the Charter: Ibid.

${ }^{88} R$. v. Whitley [1994] 3 S.C.R. 830. LEAF Factum in Equality and the Charter: Ibid.

${ }^{89} R$. v. Butler [1992] 1 S.C.R. 452. LEAF Factum in Equality and the Charter: Ibid.

${ }^{90}$ Moge v. Moge [1992] 3 S.C.R. 813. LEAF Factum in Equality and the Charter: Ibid.

${ }^{91}$ Scachter v. Canada, [1992] 2 S.C.R. 679. LEAF Factum in Equality and the Charter: Supra.

${ }^{92}$ Tremblay v. Daigle [1989] 2 S.C.R. 530. LEAF Factum in Equality and the Charter: Ibid.

${ }^{93}$ R. v. Sullivan [1991] 1 S.C.R. 489. LEAF Factum in Equality and the Charter: Ibid.

${ }^{94} R$. v. Conway, [1989] 1 S.C.R. 1659. LEAF Factum in Equality and the Charter: Ibid.

${ }^{95}$ Canadian Council of Churches v. Canada (Minister of Employment and Immigration), [1992] 1 S.C.R. 236. LEAF Factum in
} 
either not mentioned at all in the LEAF facta or, if mentioned, are included as part of an 'additive analysis".

While many of the cases cited (as well as other cases taken by LEAF) did not directly involve racialized, disabled, lesbian, or poor women on their face, a proper analytical framework I believe, would have as its starting point a conceptualization of the various forms of multiple discrimination. That is, a clear definition of intersectional, compound and overlapping discrimination, should have been presented followed by a contextual analysis of the particular discrimination evident in the case at bar placed within these definitions utilizing relevant facts to explore the impact of the particular Charter issue on women and men from diverse backgrounds. This approach would not only have assisted the Court in clearing up its own confusion regarding the various concepts, but would also have laid the groundwork for future claims of intersectional discrimination.

In fact, in the introduction to Equality and the Charter: Ten Years of Feminist Advocacy before the Supreme Court of Canada, it is acknowledged that LEAF has “...on occasion, taken shortcuts that were insufficiently attentive to the impact of LEAF's positions on more marginalized women."96 However, this begs the question of LEAF's use of 'additive analyses in lieu of a more comprehensive theoretical framework for addressing multiple sites of oppression. The reference to "more marginalized women" in itself suggests an additive analysis where White, heterosexual, able-bodied women are at the centre and all other women at the margins. I 
have some sympathy for LEAF's observation that:

... it must be acknowledged that the goal of a comprehensive equality theory that accommodates women's differences is an elusive one. The issues raised are uniquely difficult, as is translating them into legal theory and argument,"97

However, I believe that this statements premise that it is possible to develop $a$ comprehensive legal theory that accommodates all women's differences is fundamentally flawed since by definition women's differences will require more than one different legal theory. In fact they may require many such theories. Having said this, as noted above, there have been a few notable exceptions to the 'additive analysis' approach ordinarily taken by LEAF. An example is R. v. O'Connor ${ }^{\mathbf{9}}$, a case of sexual assault by a Roman Catholic bishop on four Aboriginal women who, as children, had been in a residential school where he had served as a principle as well as a priest. At the time of the sexual assaults these women were employed at the residential school under his supervision and he continued to be their spiritual advisor.

LEAF was involved in this case as a part of a coalition consisting of the Aboriginal Women's Council, the Disabled Women's Network of Canada, and the Canadian Association of Sexual Assault Centres. The coalition stated that it brought to the appeal extensive expertise in:

... (b) the life circumstances of First Nations women and of women with disabilities; (c) the relationships among inequalities based on sex, race, and disability alone or in combination, vulnerability to sexual violence and diminished access to justice...99

\footnotetext{
${ }^{97}$ Equality and the Charter, Ibid. at xxi

${ }^{98} R$. v. O'Conner (1996) 44 C.R. (4th) 1 (S.C.C.).

${ }^{99}$ Equality and the Charter, Supra, note 7, Coalition Factum in $R$. v. O'Conner at p. 430.
} 
The Coalition in its Factum put forth arguments which I believe consist largely of 'additive analysis' with some compound discrimination features. The analysis of intersectionality issues is vague and undefined.

The 'additive analysis' features contained in the Factum are laid out in paragraph 9 which states that:

...evolving contemporary disclosure jurisprudence reflects, exploits and reinforces discriminatory stereotypes about women, children, and their sexuality that are little different in their genesis or substance from the evidentiary rules abrogated by Parliament in 1983, and from the rape myths... ${ }^{\mathbf{1 0 0}}$ [emphasis added].

Here, the Factum clearly places 'women and children' at the centre of the analysis with the unstated 'norm' being that of White women.

Later in paragraph 18 of the Factum a compound discrimination analysis is offered with respect to women with disabilities. Paragraph 17 states:

People with disabilities are at least $150 \%$ as vulnerable to sexual abuse as individuals of the same age and sex who are not disabled. .. ${ }^{101}$

The reference to $150 \%$ makes it unusually explicit that this analysis is additive in nature. There is no intersectional analysis here that would expose the historical and social foundations for the stereotypical and discriminatory attitudes that men have with regard to women with disabilities. Such an intersectional analysis would provide an analytical framework that recognizes that discrimination experienced by disabled women is a distinct form of

${ }^{100}$ Equality and the Charter, Supra, note 7, Coalition Factum in $O^{\prime}$ Conner v. The Queen, para. 9 at p. 431.
${ }^{101}$ Equality and the Charter, Ibid. at 433 
Intersectionality

AYLWARD

discrimination quite apart from the discrimination experienced by disabled men and able-bodied women.

With respect to First Nations women, the focus appears to be 'additive' with a compound discriminatory analysis. That an intersectional approach had not been taken here with respect to Aboriginal women (who experience a distinct form of discrimination based on society's historical and stereotypical treatment of Aboriginal women) is a bit puzzling since contextually the case involved discrimination experienced by Aboriginal women as distinct from that experienced by either Aboriginal men or other women. Paragraph (21) of the Factum states that:

First Nations women and children are particularly vulnerable to male sexual violence. As many as 8 out of 10 First Nations women have been sexually abused or assaulted in their lives, usually on more than one occasion. The breakdown of family structures caused by the residential school system as well as the modelling of corporal discipline, has been directly linked with violence against women in aboriginal communities"

Although in paragraph 22, for example, we see an analysis of the historical and social foundation which contributes to the stereotyping of First Nations women by White men there is no analysis of a White supremacy mind set that includes both genders of the dominant group, even though an analysis of the vulnerability to sexual violence First Nations women experience at the hands of White men because of racism appears in paragraph 22. Thus, the $O^{\prime}$ Conner Factum, while not explicitly providing an intersectionality framework has however, advanced LEAF's critical thinking on issues of multiple sites of discrimination even though features of 'additive analysis' remain intact.

\footnotetext{
${ }^{102}$ Equality and the Charter, Supra, note 7, at p.434.
} 
It is essential to point out that what is being advocated in this Article is not a hierarchical approach to discrimination. What I am encouraging is a contextualized approach to discrimination, an approach that throughout its history LEAF has consistently urged the Supreme Court of Canada to take in s. 15(1) analysis. This approach was recently re-affirmed by the Court in the $\operatorname{Law}^{103}$ case. Feminist advocates have argued that a contextualized approach to the interpretation of s. 15 requires the courts to "place increasing emphasis on interpreting legal rights, benefits and penalties in light of existing societal inequalities, the ability to analyse legal problems in their social context...,104

In its Facta submitted in Andrews ${ }^{105}$, Egan $^{106}$, Eldridge $^{107}$ and R.D.S $S^{108}$ cases (among others) LEAF has also argued that the interpretative approach to s.15(1) must be a 'purposive' one and that the "...overall purpose of s.15...is to remedy or prevent discrimination against groups subject to historical disadvantage."109 This position was also re-affirmed by the Supreme Court in the Law $^{110}$ case. In Eldridge, LEAF argued that "the attainment of substantive equality

\footnotetext{
${ }^{103}$ Law, Supra, note 38 .

${ }^{104}$ Diversity and Justice: Gender Perspectives: A Guide to Gender Equality Analysis, 1998. Ottawa: Department of Justice Canada. In this Department of Justice Guide the concept of contextualized legal reasoning is supported by L'Heureaux-Dubé and McLachlin JJ.'s comments in R. v. S. (R.D.), (1997) 3 S.C.R. 484, at 506-507 which include the following: "Judicial inquiry into the factual, social and psychological context within which litigation arises is not unusual. Rather, a conscious, contextual inquiry has become an accepted step towards judicial impartiality...this process of enlargement is not only consistent with impartiality; it may also be seen as its essential pre-condition." The Department of Justice Guide goes on to point out that "The interpretation of "self-defence" in criminal law is a pre-eminent example of the way an understanding of social context can re-shape legal doctrine."

${ }^{105}$ Andrews, Supra, note 36.

${ }^{106}$ Egan v. Canada, [1995] 2 S.C.R. 513

${ }^{107}$ Eldridge v. British Columbia (Attorney General), (1997) 3 S.C.R. 624

${ }^{108} R$. v. $S$ (R.D.), Ibid., The Intervenors (Coalition of Women's Legal Education And Action Fund and National Organization Of Immigrant And Visible Minority Women Of Canada) argued in the Coalition's Factum at p. 20 that "The Interveners urge this Honourable Court to require judges to take judicial notice of the social context in which a case arises in order to give effect to the constitutional guarantee of equality enshrined in $\mathrm{s} .15$ of the Charter.

${ }^{109}$ Eldridge v. British Columbia (Attorney General) Supra, note 105, Equality and the Charter: Factum of the LEAF/Coalition, Supra, note 7 , at p.10.

${ }^{110}$ Law, Supra, note 38 .
} 
Intersectionality

AYLWARD

under s.15 ...requires close attention to social and historical context."111 Advancing a conceptual framework for intersectional analysis also requires close attention to social and historical context.

LEAF's propensity for putting forward only partial intersectional analysis or merely mentioning intersectional discrimination in its analysis in combination with 'additive analysis' features was again reflected in the case of A.(L.L.) v. Beharriell, ${ }^{112}$ a case involving the sexual assault against a woman when she was five years of age. The issue involved the disclosure to the defendant's counsel of the counselling records of the now adult Appellant. In this case, unlike the $O^{\prime}$ Conner ${ }^{113}$ case, both the victim and the accused were White. In the Beharriell case, intersectionality was merely referred to (no definition or analysis was offered) in paragraph 13 of the Factum but not elaborated upon. ${ }^{114}$ In the Eldridge $e^{115}$, case involving the exclusion of sign language interpretation from Medicare funding, the coalition of which LEAF was a part, which included the Disabled Women's Network Canada, offered an intersectionality analysis (although it was not explicitly identified as such) when it stated in its factum that: “...when analyzed in its social and historical context, the exclusion of sign language interpretation from funding under the impugned legislation has a discriminatory impact on Deaf persons contrary to s.15(1) of the Charter....,116

\footnotetext{
${ }^{111}$ Eldridge, Factum of the LEAF/Coalition, Ibid. at p.11.

${ }^{112}$ A. (L.L.) v. Beharriell

${ }^{113}$ R. v. O'Conner, Supra, note 96.

${ }^{114}$ Equality and the Charter, Supra, note 7, at p. 454.

${ }^{115}$ Eldridge, Supra, note 105.

${ }^{116}$ Eldridge, Ibid. $L E A F$ et al. Factum at p. 1.
}

Volume 1, Number 1, 2010 
Again in the case of R.D.S. ${ }^{117}$ in which LEAF formed a coalition with the National Organization of Immigrant and Visible Minority Women of Canada there is an intersectionality analysis although again it is not explicitly identified as such.

The most comprehensive analysis presented by LEAF (to date) on intersectionality and compound discrimination is contained in its Factum in the Vriend ${ }^{\mathbf{1 1 8}}$ case. This was a case involving a Charter challenge to the exclusion of sexual orientation from the Alberta human rights act. Clearly LEAF argued intersectionality in its Factum when it stated that "much lesbian discrimination should be recognized and redressible as a distinctive form of "sex" discrimination" ${ }^{\mathbf{1 1 9}}$ [emphasis added]. In support of these intersectional discrimination arguments LEAF put forward social context examples of the differential treatment afforded lesbian women.

For instance, lesbians experience particularly hostile or voyeuristic or persistent forms of sexual harassment from men. Similarly, the risk of being discharged from employment on being discovered a lesbian further diminishes the restricted job opportunities faced by lesbians because they are women. In addition, the denial of benefits for non-heterosexuals has a disparate impact on lesbians who, as women, experience greater economic disadvantage. ${ }^{\mathbf{1 2 0}}$

LEAF also recognized the complex discrimination experienced by lesbians of colour, and lesbians with disabilities.

The LEAF arguments in the Vriend ${ }^{121}$, Eldridge $e^{122}$ and $O^{\prime}$ Conner ${ }^{123}$ Facta are the closest LEAF has come to an articulated analytical framework for intersectional discrimination to date.

\footnotetext{
${ }^{117} R$. v. $R$ (R.D.), Supra, note, 102

${ }^{118}$ Vriend v. Alberta, [1998] 1 S.C.R. 493

${ }^{119}$ Vriend, Ibid. LEAF Factum at p. 13 (on file with the Author).

${ }^{120}$ Vriend, LEAF Factum, Supra, note 117, at p. 13.

${ }^{121}$ Vriend, LEAF Factum, Ibid.

${ }^{122}$ Eldridge, LEAF Factum, Supra, note 109.

${ }^{123} O$ 'Conner, LEAF Factum, Supra, note 97.
} 
However, the arguments in all three suffer from the lack of 'naming' of the specific types of discrimination LEAF is addressing and from the lack of a coherent framework of analysis which, in my view, is essential in order to assist the Court in developing intersectional and compound equality jurisprudence.

\section{(Re)Conceptualizing Intersectionality as an 'Analogous' Ground of Discrimination: Law v. Canada}

In the recent Supreme Court of Canada case of Law v. Canada ${ }^{\mathbf{1 2 4}}$, a s. 15(1) Charter challenge on the basis of age was brought by a 30-year-old, able-bodied woman, without dependent children, who was denied survivor's benefits under the Canadian Pension Plan ${ }^{\mathbf{1 2 5}}$ (CPP). The Plan had a threshold age of 45 years upon the death of a spouse before the survivor could receive benefits unless the survivor was disabled or had dependent children. In the course of determining the question of whether or not the age distinctions contained in the CPP discriminated against widows and widowers under the age of 45, and whether or not such an infringement could be justified under s. 1 of the Charter, Iacobucci J., writing for the Court, set out the "basic principles" and the "proper approach" to s. 15(1) equality analysis. ${ }^{\mathbf{1 2 6}}$

Iacobucci J., is careful however, to point out that the basic principles outlined in the case are set out as 'guidelines' only to assist the courts in conducting s.15 equality analysis and not as

\footnotetext{
${ }^{124}$ Law, Supra, note 38 .

${ }^{125}$ Canada Pension Plan, R.S.C., 1985, c. C-8, ss. 44(1)(d) [am. C. 30 (2nd Supp), s. 13], 58(1)(a) [am. Idem. s.26].

${ }^{126}$ Law, Supra, note 38, per Iacobucci J., at 509.
} 
a rigid test which must be 'mechanically' applied in every case. ${ }^{\mathbf{1 2 7}}$

The Court, after canvassing the existing s.15 jurisprudence concludes that a court called upon to make a determination of a discrimination claim under s.15 should make three 'broad' inquiries:

First, does the impugned law (a) draw a formal distinction between the claimant and others on the basis of one or more personal characteristics, or (b) fail to take into account the claimant's already disadvantaged position within Canadian society resulting in substantively differential treatment between the claimant and others on the basis of one or more personal characteristics? If so, there is differential treatment for the purpose of s. 15(1). Second, was the claimant subject to differential treatment on the basis of one or more of the enumerated and analogous grounds? And third, does the differential treatment discriminate in a substantive sense, bringing into play the purpose of s.15(1) of the Charter in remedying such ills as prejudice, stereotyping, and historical disadvantage? The second and third inquiries are concerned with whether the differential treatment constitutes discrimination in the substantive sense intended by s. $15(1) .^{\mathbf{1 2 8}}$

Iacobucci J. then summarizes the jurisprudence on the purpose of s. 15(1) which he says, in general terms is to "...prevent the violation of essential human dignity and freedom through the imposition of disadvantage, stereotyping, or political or social prejudice, and to promote a society in which all persons enjoy equal recognition at law as human beings or as members of Canadian society, equally capable and equally deserving of concern, respect and consideration". 129

In order for a claimant to establish discrimination, there must be a conflict between either the purpose or effect of the impugned law and the purpose of s.15. Additionally the Court says

${ }^{127} \mathrm{Law}$, Ibid. per Iacobucci J., at 509.

${ }^{128}$ Law, Supra, note 38, per Iacobucci J., at 509.

${ }^{129}$ Law, Ibid. per Iacobucci J., at 549. 
that the determination of whether or not such a conflict exists requires a contextual analysis surrounding both the claim and the claimant. ${ }^{\mathbf{1 3 0}}$ It is both the perspective of the person making the claim of discrimination (subjective) and the perspective of the reasonable person (objective) in similar circumstances, who takes into account the contextual factors relevant to the claim that determines whether there is a demeaning of dignity. ${ }^{\mathbf{1 3 1}}$

The Court then sets out some "important contextual factors" which will influence the determination of whether s. 15(1) has been infringed but is careful to point out that this list of factors is not closed. ${ }^{\mathbf{1 3 2}}$ Some of the factors articulated by the Court in the Law case include, but are not limited to, the following:

Pre-existing disadvantage, stereotyping, prejudice, or vulnerability experienced by the individual or group at issue. The effects of a law as they relate to the important purpose of s. 15(1) in protecting individuals or groups, who are vulnerable, disadvantaged, or members of "discrete and insular minorities" should always be a central consideration... ${ }^{\mathbf{1 3 3}}$

Although the Court is quick to point out that membership in a historically more advantaged or disadvantaged group or groups is not determinative of an infringement of s. 15(1), the fact that this factor exists will favour a finding of a s.15 (1) infringement. ${ }^{\mathbf{1 3 4}}$ Iacobucci J., also asserts the proposition that, while the person claiming discrimination under s. 15(1) bears the onus of establishing an infringement of equality rights no evidence need be adduced:

\footnotetext{
${ }^{130}$ Law, Ibid. at 549 .

${ }^{131}$ Law, Ibid. at 541 .

${ }^{132}$ Law, Supra, note 38, at 550.

${ }^{133}$ Law, Ibid. at 550.

${ }^{134}$ Law, Ibid. at 551 .
} 
... evidence need not be introduced in order to show a violation of human dignity or freedom because in most cases where differential treatment is based on one or more enumerated or analogous grounds, this will be enough to found an infringement of s.15 (1) since a violation of human dignity will be evident on the basis of judicial notice and logical reasoning that the distinction is discriminatory within the meaning of the provision. $^{135}$

Iacobucci J. goes on to talk about the principles of enumerated and analogous grounds by looking at past jurisprudence relating to the indications of analogous grounds. He notes that these principles have been developing over time and he concludes that in their evolution, the notion of basing a claim of discrimination on only one ground has given way to the recognition that a claim can be based on more than one ground. ${ }^{\mathbf{1 3 6}}$ Such an approach, the Court recognizes, corresponds to the "purposive and contextual approach to equality under s. 15(1)". ${ }^{137}$ Iacobucci J. goes on to set out the test for a finding of an analogous ground of discrimination:

Where a party brings a discrimination claim on the basis of a newly postulated analogous ground, or on the basis of a combination of different grounds, this part of the discrimination inquiry must focus upon the issue of whether and why a ground or confluence of grounds is analogous to those listed in s.15(1). This determination is made on the basis of a complete analysis of the purpose of s. 15(1), the nature and situation of the individual or group at issue, and the social, political and legal history of Canadian society's treatment of the group. A ground or grounds will not be considered analogous under s. 15(1) unless it can be shown that differential treatment premised on the ground or grounds has the potential to bring into play human dignity. If the court determines that recognition of a ground or confluence of grounds as analogous would serve to advance the fundamental purpose of s. 15(1), the ground or grounds will then be so recognized. ${ }^{\mathbf{1 3 8}}$

Iacobucci J., affirms that there is "... no reason in principle, therefore, why a

discrimination claim positing an intersection of grounds cannot be understood as analogous to, or

${ }^{135}$ Law, Ibid. at 552.

${ }^{136}$ Law, Supra, note 38 , at 523

${ }^{137}$ Law, Ibid. at 554.

${ }^{138}$ Law, Ibid. at 554. 
as a synthesis of, the grounds listed in s.15(1)."139 Based on this assertion intersectionality as an 'analogous' ground of discrimination under s. 15(1) of the Charter would be a distinct ground of discrimination and must be argued as such.

For example, in the case of Black women and sexual assault the focus of the arguments would be quite different then those proffered in the case of sexual assault and White women. Instead of focusing on the discriminatory stereotypes about women and their sexuality (with the unstated 'norm' of White), the focus would be on the racist and discriminatory stereotypes about Black women, and their sexuality. The court is then directed to look to the purpose of s. 15(1) which the Court in Law re-affirms is to "prevent the violation of essential human dignity and imposition of disadvantage, stereotyping, or political or social prejudice...."140 Next the court considers the nature and or situation of the group at issue, and the social, political and legal history of Canadian society's treatment of the group. This history and treatment of Black women will be very different from the history and treatment of White women, because White women do not experience racist sexual stereotypes or colonial or imperialist subjection with its legacy of slavery. Similarly, other racialized women will experience racist sexual stereotypes of a different nature and their treatment in Canadian society will also be different. While Black women will have commonalities with regard to the racism experienced by Black men, the experience of Black women will be distinct because they are subjected to male sexual violence.

An intersectional discrimination claim by women with disabilities and their experience of

\footnotetext{
${ }^{139}$ Law, Ibid. at 554 .

${ }^{140}$ Law, Supra, note 38, at 549.
} 
sexual assault would be expressed in terms of a distinct form of discrimination based on stereotypes about disabled women's sexuality. In all intersectional claims the analytical framework would begin with a discussion of the various forms of multiple oppression, then proceeded to a contextualized analysis of the particular form(s) present in the case at hand rather than as an 'add-on' to the discrimination experienced by White, heterosexual, able-bodied, middle-class women.

Intersectional analysis allows us to formulate legal theory under s. 15(1) of the Charter that addresses the reality of diverse women's lives while assisting the courts in fashioning a remedy that is fitting in the circumstances. It also allows us to better expose the inequalities in society, the underlying basis for them, and our own roles in their perpetuation.

Subsequent to the decision in the $\operatorname{Law}^{141}$ case the Supreme Court of Canada again had the opportunity to consider an intersectionality analysis in the Corbiere ${ }^{142}$ case. This case involved a s. 15(1) Charter ${ }^{\mathbf{1 4 3}}$ challenge by off-reserve members of the Batchewana Indian Band to s.77(1) of the Indian Act $^{\mathbf{1 4 4}}$ which stated that Band members had to be living on the reserve in order to vote in Band elections. The Federal Court Trial Division held that the section infringed the equality provisions of the Charter ${ }^{145}$ and could not be saved under s. 1 and granted a declaration of invalidity of s. 77(1) in its entirety and suspended the declaration for ten months. This decision was upheld by the Federal Court of Appeal which modified the remedy by asserting that

\footnotetext{
${ }^{141}$ Law, Supra, note 38 .

${ }^{142}$ Corbiere v. Canada (Minister of Indian and Northern Affairs) [1999] 2 R.C.S. 203.

${ }^{143}$ Charter, s. 15 , Supra, note 3

${ }^{144}$ Indian Act, R.S.C., 1985, c. I-5, s. 77(1).

${ }^{145}$ Charter, Ibid.
} 
the appropriate remedy was a Constitutional exemption because other Bands might be able to demonstrate an Aboriginal right under s.55 of the Constitution Act ${ }^{146}$ to exclude non-residents from voting. The Federal Court of Appeal instead declared that the words "and is ordinarily resident on the reserve" in s. $77(1)$ violated s.15(1) of the Charter $^{147}$ only in relation to the Batchewana Band and the declaration of invalidity was not suspended. The Supreme Court of Canada dismissed an appeal but modified the remedy designed by the Federal Court of Appeal to a suspension of the declaration of invalidity for eighteen months. ${ }^{148}$

All of the Supreme Court Justices agreed that "Aboriginality-residence" or "off-reserve band member status" constitutes an analogous ground of discrimination. ${ }^{\mathbf{1 4 9}}$ They disagree however, on the criteria that identify an analogous ground. ${ }^{\mathbf{1 5 0}}$ The Supreme Court of Canada applied the three step approach to s. 15(1) analysis articulated in the Law $^{151}$ case. This three step framework as noted above involves three broad inquiries:

(a) Does the impugned law draw a formal distinction between the claimant and others on the basis of one or more personal characteristics, or (b) fail to take into account the claimant's already disadvantaged position within Canadian society resulting in substantially differential treatment between the claimant and others on the basis of one or more personal characteristics? (B) Is the claimant subject to differential treatment based on one or more enumerated and analogous grounds? And (C) Does the differential treatment discriminate, by imposing a burden upon or withholding a benefit from the claimant in a manner which reflects the stereotypical application of presumed group or personal characteristics, or which otherwise has the effect of perpetuating or promoting the view that the individual is less capable or worthy of recognition or value as a human

\footnotetext{
${ }^{\mathbf{1 4 6}}$ Constitution Act, 1982, s.55 [am. R.S.C., 1985, App.II, No. 46], 52.

${ }^{147}$ Charter, Supra, note 3

${ }^{148}$ Corbiere, Supra, note 140 at pp. 238-243.

${ }^{149}$ Corbiere, Ibid., per Lamer C.J. and Cory, McLachlin, Major and Bastarache JJ. at p. 216. [Judgment delivered by McLachlin and Bastarache JJ.].

${ }^{150}$ Corbiere, Ibid. at p. 216

${ }^{151}$ Law, Supra, note 38 .
} 
being or as a member of Canadian society, equally deserving of concern, respect and consideration? ${ }^{\mathbf{1 5 2}}$

Five of the Supreme Court Justices, Lamer C.J. and Cory, McLachlin, Major and Bastarache JJ. disagreed with L'Heureaux-Dubé J.'s (and those concurring with her) concept of engaging in a contextual analysis at the second stage of a s.15(1) inquiry which is the enumerated or analogous ground determination. In other words, the Majority would maintain a distinction between the second-stage analysis of enumerated or analogous grounds and the thirdstage analysis of discrimination articulated in the Law case. According to the Majority in Corbiere the former does not require a 'contextualized' analysis while the latter does. Based on this distinction, the Majority opinion is that although both stages of the analysis (enumerated or analogous ground analysis) and (contextual discrimination analysis) are concerned with discrimination and the violation of the presumption of the equal dignity and worth of every human being, the analogous grounds serve only as "jurisprudential markers for suspect distinctions":

They function conceptually to identify the sorts of claims that properly fall under s.15. By screening out other cases, they avoid trivializing the s.15 equality guarantee and promote the efficient use of judicial resources. Once a distinction on an enumerated or analogous ground is established, the contextual and fact-specific inquiry proceeds to whether the discrimination amounts to discrimination in the context of the particular case. The second and third stages are distinct: the former asks whether the distinction is on the basis of an enumerated or analogous ground, the latter whether that distinction on the facts of the case affronts s.15. Affirmative answers to both inquiries are a precondition to establishing a constitutional claim. ${ }^{\mathbf{1 5 3}}$

\footnotetext{
${ }^{152}$ Corbiere, Supra, note 140 at p. 249 per L’Heureaux-Dubé J., quoting Iacobucci J., Law v. Canada (Minister of Employment and Immigration Supra, note 38, at para.88.

${ }^{153}$ Corbiere, Ibid., Majority decision at p. 219.
} 
The criteria that the Majority in the Corbiere case identify as determinative of an analogous ground are grounds that are based on:" ...characteristics that we cannot change or that the government has no legitimate interest in expecting us to change to receive equal treatment under the law... [in other words] s.15 targets the denial of equal treatment on grounds that are actually immutable, like race, or constructively immutable, like religion... other factors associated with enumerated and analogous grounds, like the fact that the decision adversely impacts on a discrete and insular minority or a group that has been historically discriminated against, may be seen to flow from the central concept of immutable or constructively immutable personal characteristics, which too often have served as illegitimate and demeaning proxies for merit-based decision making. ${ }^{\mathbf{1 5 4}}$

On the other hand, L'Heureaux-Dubé J.'s opinion (concurred in by Gonthier, Iacobucci and Binnie JJ.) was that a "purposive and contextual" analysis must take place at all three stages of the $L a w^{\mathbf{1 5 5}}$ test. In determining whether the differential treatment is an analogous ground a "purposive " and "contextual" analysis requires that consideration be given not only to the "nature and situation of the individual or, group at issue"156 but also to the "social and legal history of Canadian society's treatment of that group" [emphasis added]. ${ }^{\mathbf{1 5 7}}$

Aside from the 'immutable' characteristic of the individual or group, L'Heureaux-Dubé

\footnotetext{
${ }^{154}$ Corbiere, Supra, note 140 Majority decision at p. 220.

${ }^{155}$ Law, Supra, note 38 .

${ }^{156}$ Corbiere, Ibid. at p. 252 per L'Heureaux-Dubé quoting from Law para. 93.

${ }^{157}$ Corbiere, Ibid. at p. 252.
} 
J. states that whether those defined by the characteristic “... are lacking in political power, disadvantaged, or vulnerable to becoming disadvantaged or having their interests overlooked is also central to the analogous ground analysis". ${ }^{158}$ Additionally, according to L'Heureaux-Dubé J., other criteria may be considered in subsequent cases and "none of the above indicators are necessary for the recognition of an analogous ground or combination of grounds [emphasis in original]. $^{159}$

In terms of intersectionality L'Heureaux-Dubé J. says that “...The second stage must therefore be flexible enough to adapt to stereotyping, prejudice, or denials of human dignity and worth that might occur in specific ways for specific groups of people, to recognize that personal characteristics may overlap or intersect (such as race, band membership, and place of residence in this case), and to reflect changing social phenomena or new or different forms of stereotyping or prejudice. As this Court held in Law, supra, at para. 73: "The possibility of new forms of discrimination denying essential human worth cannot be foreclosed.”,160

As indicated, both the Majority and the Minority agree that in the Corbiere ${ }^{161}$ case several factors led them to conclude that recognizing off-reserve band member status as an analogous ground would accord with the purposes of s.15(1). However, the Majority conclusion that contextual analysis at the determination of an analogous grounds stage of the inquiry is not required is simply wrong and not in accordance with the Supreme Court's own pronouncement

\footnotetext{
${ }^{158}$ Corbiere, Supra, note 140 at p. 152 per L'Heureaux-Dubé quoting from Andrews and Law at para. 29.

${ }^{159}$ Corbiere, Ibid. at p. 152

${ }^{160}$ Corbiere, Ibid. at p. 253.

${ }^{161}$ Corbiere, Ibid.
} 
in the $\mathrm{Law}^{162}$ case. Further, the Majority does not undertake an intersectional discrimination analysis that is discernable on the face of the decision.

For the purposes of an Intersectional discrimination analysis, the position taken by L'Heureaux-Dubé J., and concurred in by Gonthier, Iacobucci and Binnie JJ. is preferable since it allows Black women, racialized women, poor women, disabled women, and lesbian women to argue for a recognition of Intersectional discrimination as a distinct form of discrimination under s.15(1) based on the social and legal history of Canadian Society's treatment of them. The Majority's restrictive approach to the second stage of the Law framework does not allow for this kind of contextual analysis.

The Majority in the Corbiere ${ }^{163}$ case assert that it is irrelevant that a contextual analysis is not undertaken at this stage since a contextual analysis will occur at the third stage of the Law ${ }^{\mathbf{1 6 4}}$ framework when a determination of discrimination is undertaken. They also assert that the result will likely be the same whether there is a finding of no analogous ground or a finding that there is no discrimination affecting human dignity. However, this analysis ignores the fact that if there is a finding at the second stage of the $\operatorname{Law}^{\mathbf{1 6 5}}$ analysis that the discrimination experienced is not an analogous ground under s. 15(1) the courts/claimants will never have an opportunity to 'contextualize' or 'ground' the treatment in the social and legal history of Canadian society's treatment of that individual or group.

\footnotetext{
${ }^{162}$ Law, Supra, note 38. See L'Heureaux-Dubé analysis in Corbiere of the Law decision on this issue at pp. 251-252.

${ }^{163}$ Corbiere, Supra, note 140.

${ }^{164}$ Law, Supra, note 38 .

${ }^{165}$ Law, Ibid.
} 
Focussing the analysis on "immutable" characteristics of the individual or group rather than on society's discriminatory treatment of that individual or group fails to address the real problem of discrimination. While the outcome in the Corbiere ${ }^{166}$ case suggests that the Supreme Court applied an Intersectional discrimination analysis (albeit not articulated by the Majority) the reasoning leaves a lot to be desired.

The application of the $\mathrm{Law}^{167}$ case in this context further supports the view that the courts require a clearly articulated framework for analysing the intersection of race, class, gender, sexual orientation, and disability that will assist them in developing intersectional equality jurisprudence. The reasoning of L'Heureaux-Dubé, Gonthier, Iacobucci and Binnie JJ. in the Corbiere $^{168}$ case combined with the Court's pronouncement in the Law $^{169}$ case that intersecting grounds are analogous grounds under s.15(1) suggests that at least some of the Supreme Court justices are open to such an analysis thus laying the groundwork for future cases despite the enigmatic analysis in Corbiere. ${ }^{170}$

\section{Conclusion}

The Supreme Court of Canada decision in the case of Law v. Canada ${ }^{171}$ has recognized that Intersectional discrimination is an 'analogous' ground of discrimination under s. 15(1) of the

\footnotetext{
${ }^{166}$ Corbiere, Supra, note 140

${ }^{167}$ Law, Supra, note 38.

${ }^{168}$ Corbiere, Ibid.

${ }^{169}$ Law, Ibid.

${ }^{170}$ Corbiere, Ibid.

${ }^{171}$ Law, Ibid.
} 
Charter $^{172}$. Because of its categorization as an 'analogous' ground it can be argued that discrimination experienced by Black women, racialized women, women with disabilities, lesbian women, and poor women constitutes a separate and distinct ground of discrimination from that experienced by White, heterosexual, able-bodied, middle-class women. As such, cases similar to Virend, ${ }^{173} \mathrm{O}^{\prime}$ Conner, ${ }^{174}$ and Eldridge,${ }^{175}$ which involved distinct discrimination faced by Aboriginal women and disabled women should, in the future, not be argued on the basis of 'compound' discrimination but on the basis of Intersectionality.

Compound discrimination arguments are themselves distinct from Instersectional discrimination and overlapping discrimination. Compound discrimination involves the concept of discrimination against women plus the added disadvantage of some other ground such as racialization, disability, lesbianism, or class. In some cases, compound discrimination is the appropriate analytical framework under s.15. However, it must be kept in mind that it is not the only analytical framework for a s.15 multiple discrimination analysis and does not constitute a distinct ground of discrimination in the same way that Intersectional discrimination does.

Arguments cantered around 'overlapping' grounds of discrimination may also be appropriate in some circumstances. However, it should be kept in mind that 'overlapping' discrimination arguments invariably lead to the complainant having to strategically consider on which of the grounds she wishes to place her evidentiary focus thus contributing to the tendency

\footnotetext{
${ }^{172}$ Charter, Supra, note 3.

${ }^{173}$ Virend, Supra, note 116.

${ }^{174}$ O'Conner, Supra, note 109.

${ }^{175}$ Eldridge, Supra, note 103.
} 
of the courts and some advocates to 'erase' race in favour of a less 'controversial' ground of discrimination.

The Supreme Court of Canada has opened the door a crack to allow for the development of a proper Intersectional discrimination analysis. It is up to those appearing before the courts on behalf of all women to enlarge the crack by refining and defining Intersectional analysis. In this endeavour LEAF has more than a minimal role to play.

In all equality rights cases going before the Courts in which LEAF intervenes or initiates litigation, the starting point should be a multiple discrimination framework that clearly defines Intersectional, Compound and Overlapping grounds of discrimination. From there the analysis should proceed to a 'contextualized' approach to discrimination on the facts of the case. This two pronged approach will clarify not only LEAF's approach to multiple discrimination analysis but will also assist the Court in developing Intersectionality equality jurisprudence. 